\title{
EFFECT OF VITAMIN E (DL-ALL-RAC-A-TOCOPHEROL ACETATE) AND NANO PARTICLES OF SELENIUM ON GROWTH, SURVIVAL, BODY COMPOSITION AND WHOLE BODY GLUTATHIONE PEROXIDASE (GPX) AND MALONDIALDEHYDE (MDA) IN RUTILUS KUTUM (KAMENSKY, 1901)
}

\section{Davoud TAHMASBI *, Saeid GORGIN **, Mohammad MAZENDARANI and Mohammad SUDAGAR}

* Gorgan University of Agricultural Sciences and Natural Resources, Fisheries and Exploitation Department, College of Fisheries and Environment, Gorgan, Iran

** Gorgan University of Agricultural Sciences and Natural Resources, Department of Fisheries and Exploitation, College of Fisheries and Environment, Gorgan, Iran, sgorgin@gau.ac.ir

DOI: 10.1515/trser-2017-0014

KEYWORDS: vitamin E, nano-selenium, growth performance, glutathione peroxidase, malondialdehyde.

\section{ABSTRACT}

The effect of vitamin $\mathrm{E}\left(100 \mathrm{mg} \mathrm{kg}^{-1}\right)$ and nano-selenium $\left(1 \mathrm{mg} \mathrm{kg}^{-1}\right)$, which have a nutritional relationship separately and in combination, was investigated on growth, survival, carcass composition, body glutathione peroxidase activity, and body malondialdehyde content of Rutilus kutum. Results showed that vitamin E is capable of improving growth, FCR and WG in Kutum fingerlings; however, nano-selenium is not. According to this study, vitamin E can improve growth and selenium can improve glutathione peroxidase activity in Rutilus kutum larvae.

RESUMEN: Efecto de la vitamina E (DL aflta tocoferol acetato) y nano-partículas en el crecimiento, supervivencia, composición corporal, peroxidasa glutatión corporal (GPX) y malondialdehído en Rutilus kutum (Kamensky, 1901).

Se investigó el efecto de la vitamina $\mathrm{E}\left(100 \mathrm{mg} \mathrm{kg}^{-1}\right)$ y el nano-selenio $\left(1 \mathrm{mg} \mathrm{kg}^{-1}\right)$, compuestos que poseen una relación nutricional tanto de forma separada como combinada, sobre el crecimiento, supervivencia, composición corporal, actividad del peroxidasa glutatión corporal y en el contenido de malondialdehído en el ciprínido de los Rutilis kutum. Los resultados mostraron que la vitamina $\mathrm{E}$ es capaz de mejorar el crecimiento en juveniles de la especie; sin embargo, el nano-selenio, no. Con acuerdo a este estudio, la vitamina $\mathrm{E}$ puede promover el crecimiento y el selenio puede aumentar la actividad de la peroxidasa glutatión en las larvas de Rutilis kutum.

REZUMAT: Efectul vitaminei E (DL-all-rac- $\alpha$-tocoferol acetat) și a nanoparticulelor de seleniu asupra ratei de creștere, ratei de supraviețuire, compoziției corpului, activității glutation-peroxidazei (GPx) și concentrației generale de malondialdehidă în Rutilus kutum (Kamensky, 1901).

S-a studiat efectul vitaminei E (100 mg kg-1) și nano-seleniului $\left(1 \mathrm{mg} \mathrm{kg}^{-1}\right)$, cu rol nutrițional, administrate separat și combinat asupra ratei de creștere, ratei de supraviețuire, compoziției carcasei, asupra speciei Rutilus kutum. Rezultatele au arătat că vitamina E este capabilă să îmbunătățească creșterea, FCR și WG la puietul de Rutilus kutum; însă, nanoseleniul nu a demonstrat efecte asupra acestor indicatori. Conform acestui studiu, vitamina $\mathrm{E}$ poate îmbunătăți creșterea iar seleniul poate îmbunătăţi activitatea glutation-peroxidazei la alevinii de Rutilus kutum. 


\section{INTRODUCTION}

Caspian Kutum is one of the endemic species of the Caspian Sea, a popular fish, particularly in north Iran, due to meat quality and marketability (Ebrahimi et al., 2012; Afkhami et al., 2014). It is a valuable species for fishing industry (Ouraji et al., 2011) because of its distribution along the Caspian coastline (Heyrati et al., 2007). To restock the population of the Caspian Sea species the Iranian fisheries organization produces and releases a huge number of fingerlings annually, which, Caspian kutum comprises $89 \%$ of total bony fish species (Abdolhay et al., 2011). In restocking centers, Caspian Kutum larva feed on zooplanktons and a formulated diet (Ebrahimi et al., 2012). The formulated diet should be balanced with respect to all dietary components to allow the larvae to reach higher weight and to have adequate resistance to enter seawater.

Vitamin E is predicated to all materials acting as alpha-tocopherol (Parker and Parker, 2011). Tocopherols protect tissue against the damages caused by lipid oxidation (Hamre, 2011). Vitamin $E$ is necessary to maintain meat quality, immune system, natural stability of blood cells against hemolysis, capillary permeability, and heart muscles (Halver and Hardy, 2002).

Selenium is one of the elements necessary in the natural life cycle of all organisms including fish (Köhrle, 2004). Selenium is important because it is involved in glutathione peroxidase (GPx) structure. This enzyme protects cells and tissues against oxidative damages (Watanabe et al., 1997).

Vitamin E and selenium have an obvious nutritional relationship. This relationship has been studied in a number of fish species. The results show that the symptoms of combined vitamin $\mathrm{E}$ and selenium shortage are muscular dystrophy, presence of muscular proteins in plasma and anemia (Bell et al., 1985, 1986, 1987; Gatlin et al., 1986; Poston et al., 1976).

Nano-materials have special properties. Recently, nano-selenium has attracted attention due to high bioavailability and low toxicity (Wang et al., 2007a). The aim of the present study was to investigate the singular and combined effects of vitamin $\mathrm{E}$ and nanoselenium on growth, survival, carcass composition, whole body GPx activity, and malondialdehyde content of Caspian kutum fingerlings. This was performed at the aquaculture laboratory of the Gorgan University of Agricultural Sciences and Natural Resources, Gorgan, Iran, over six weeks.

\section{MATERIAL AND METHODS}

Nano-selenium used in this study was provided from Nanosani Co. (Mashhad, Iran). Average particle size of this product was $50 \mathrm{~nm}$. Also, Dl-all-rac- $\alpha$-tocopherol acetate (Sigma Chemical Co., Steinheim, Germany) was used as a vitamin E source, because of high stability and bioavailability to fish (NRC, 1993). Basal diet composition is presented in table 1. Four diets were used in this study: 1 - the control diet without nano-selenium and vitamin $\mathrm{E}$ supplementation (control), 2 - the control diet supplemented with $100 \mathrm{mg} / \mathrm{kg}$ vitamin $\mathrm{E}$ (T-1), 3 - the control diet supplemented with one $\mathrm{mg} / \mathrm{kg}$ nano-selenium (T-2), and 4 - the control diet supplemented with $100 \mathrm{mg} / \mathrm{kg}$ vitamin $\mathrm{E}$ and one $\mathrm{mg} / \mathrm{kg}$ nano-selenium (T-3). To produce the diets dry ingredients were mixed and then oil and water were added to the mixture. Nanoselenium, being a solution, was added to the diets in combination with water, whereas Dl-allrac- $\alpha$-tocopherol acetate was added in combination with oil. The resultant dough was then passed through a mesh to form threads. The threads were air-dried and crushed into appropriate size before use. 
Table 1: Formulation and proximate composition of experimental diets; * Vitamin mixture was manually provided according to feed requirements of the fish: (each $\mathrm{kg}^{-1}$ diet): vitamin $\mathrm{A}, 10,000 \mathrm{IU}$; vitamin $\mathrm{D}_{3} 2000 \mathrm{IU}$; vitamin $\mathrm{K}, 20 \mathrm{mg}$; vitamin $\mathrm{B}_{1}$, $400 \mathrm{mg}$; vitamin $\mathrm{B}_{2}$, $40 \mathrm{mg}$; vitamin $\mathrm{B}_{6}$, $20 \mathrm{mg}$; vitamin $\mathrm{B}_{12}, 0.04 \mathrm{mg}$; choline chloride, 1,200 mg; folic acid, 10 mg; niacin, $200 \mathrm{mg}$; ** Mineral mixture (mg g$\left.{ }^{-1}\right): \mathrm{CaCO}_{3} 36 ; \mathrm{KH}_{2} \mathrm{PO}_{4} 502 ; \mathrm{MgSO}_{4} 7 \mathrm{H}_{2} \mathrm{O} 162$.

\begin{tabular}{|c|c|}
\hline Ingredients & $\%$ \\
\hline Soybean meal & 34 \\
\hline Fish meal & 30 \\
\hline Corn flour & 13 \\
\hline Wheat flour & 12 \\
\hline Fish oil & 7 \\
\hline Vitamin mix* & 2 \\
\hline Mineral mix** & 2 \\
\hline Proximate composition & $\%$ \\
\hline Moisture & 11.3 \\
\hline Crude protein & 38.8 \\
\hline Lipid & 8.4 \\
\hline Ash & 10.5 \\
\hline
\end{tabular}

Fish and experimental conditions

Caspian kutum fingerlings with the average weight of $250 \pm 0.03 \mathrm{mg}$, were provided from Teleost Propagation Center of Sijaval, Bandar Torkman, Iran. The fish were allowed to acclimatize to experimental condition in two $500 \mathrm{l}$ tanks for two weeks. During the acclimation period the fish were fed with commercial feed (kutum starter feed, protein $=30 \%$, fat $=10 \%$; Mazandaran Feed Co.). After the acclimation, 480 fish were stocked into 12 tanks (100 l). Each of the aforementioned diets were offered to three tanks.

During the trial, fish were fed with their corresponding diet $(12 \%$ body weight per day) thee times a day (08:00, 12:00 and 16:00). Wastes were daily siphoned from the tanks. Fifty percent of the tanks' water content was replaced with fresh water daily. Water quality was periodically monitored. Temperature was 20.3-24.8, $\mathrm{pH}$ was 7.3-7.6 and oxygen was higher than $7.8 \mathrm{ppm}$. The fish were maintained under natural photoperiod during the experiment.

The diets and fish carcass composition was determined by standard methods suggested by (AOAC, 2002). Moisture content was determined with oven at $105^{\circ} \mathrm{C}$ until reaching to a constant weight. Ash was determined by combustion at $550^{\circ} \mathrm{C}$ for $12 \mathrm{~h}$. Protein was determined by Kjeldahl method after acid digestion. Fat was determined by Soxhelt apparatus using ether petroleum for six h. The fish weight was recorded at the experiment initiation and fortnightly thereafter to adjust feed amount. The feed conversion ratio (FCR) and weight gain (WG\%) were evaluated by the following formulas: Weight gain $(\mathrm{WG} \%)=\left[\left(\mathrm{W}_{\mathrm{F}}-\mathrm{W}_{\mathrm{I}}\right) / \mathrm{W}_{\mathrm{I}}\right] \times$ 100

Feed conversion ratio $($ FCR $)=[$ Total feed intake $(\mathrm{g}) /$ Total wet weight gain $(\mathrm{g})]$.

To determine GPx and MDA, the fish whole body was first washed in sterile phosphate buffered saline (137 mM NaCl, $2.7 \mathrm{mM} \mathrm{KCl,} 4.3 \mathrm{mM} \mathrm{Na}_{2} \mathrm{HPO}_{4} .7 \mathrm{H}_{2} \mathrm{O}$, pH 7.3) and then one grame sample was homogenized in $10 \mathrm{ml}$ in same buffer. The homogenized sample was centrifuged (5,000 g) and supernatant was separated for assay. The supernatant was stored at $-70^{\circ} \mathrm{C}$ until analyses. 
GPx was determined according to Bell et al. (1986) and expressed as $\mathrm{U} \mathrm{mg}^{-1}$ protein. The supernatant total protein was determined according to Peterson (1977). Bovine serum albumin was used as standard. The sample MDA was determined by Kei (1978) method.

Statistics were performed using SPSS program version 16. One way ANOVA was used to determine the significant $(\mathrm{P}<0.05)$ difference among the groups.

\section{RESULTS AND DISSCUSION \\ Growth and carcass composition}

T-1 and T-3 groups had a significantly $(\mathrm{P}<0.05)$ higher final weight and weight gain, as well as lower FCR, compared to the control and T-2 groups (Tab. 2). There was no significant $(\mathrm{P}>0.05)$ difference in survival among the treatments (Tab. 2). There was no significant difference $(\mathrm{P}>0.05)$ in carcass moisture, protein, lipid, and ash content among the treatments (Tab. 3).

Table 2: Effect of vitamin E and nano-selenium of growth parameters of Caspian Kuttum.

\begin{tabular}{|l|l|l|l|l|}
\hline Group/treatment & Control & $\mathrm{T}-1$ & $\mathrm{~T}-2$ & $\mathrm{~T}-3$ \\
\hline Initial weight $(\mathrm{g})$ & $0.27 \pm 0.02^{\mathrm{a}}$ & $0.23 \pm 0.02^{\mathrm{a}}$ & $0.26 \pm 0.03^{\mathrm{a}}$ & $0.22 \pm 0.04^{\mathrm{a}}$ \\
\hline Final weight $(\mathrm{g})$ & $0.86 \pm 0.02^{\mathrm{b}}$ & $0.94 \pm 0.01^{\mathrm{a}}$ & $0.85 \pm 0.02^{\mathrm{b}}$ & $0.92 \pm 0.03^{\mathrm{a}}$ \\
\hline Survival rate (\%) & $95 \pm 2.5^{\mathrm{a}}$ & $96.6 \pm 1.4^{\mathrm{a}}$ & $95^{\mathrm{a}}$ & $97.5 \pm 2.5^{\mathrm{a}}$ \\
\hline WG & $212 \pm 21^{\mathrm{b}}$ & $299 \pm 37^{\mathrm{a}}$ & $223 \pm 26^{\mathrm{b}}$ & $321 \pm 61^{\mathrm{a}}$ \\
\hline FCR & $4.2 \pm 0.2^{\mathrm{b}}$ & $3.6 \pm 0.2^{\mathrm{a}}$ & $4.3 \pm 0.2^{\mathrm{b}}$ & $3.6 \pm 0.2^{\mathrm{a}}$ \\
\hline
\end{tabular}

Table 3: Whole-body proximate compositions (\% live weight basis) of kutum fingerlings after feeding trial.

\begin{tabular}{|l|l|l|l|l|}
\hline Composition & Control & T-1 & T-2 & T-3 \\
\hline Moisture & $73.1 \pm 0.4^{\mathrm{a}}$ & $73.6 \pm 0.6^{\mathrm{a}}$ & $73.5 \pm 0.6^{\mathrm{a}}$ & $73 \pm 0.9^{\mathrm{a}}$ \\
\hline Crude protein & $12.4 \pm 0.3^{\mathrm{a}}$ & $12.5 \pm 0.2^{\mathrm{a}}$ & $12.5 \pm 0.2^{\mathrm{a}}$ & $12.7 \pm 0.1^{\mathrm{a}}$ \\
\hline Crude lipid & $11.2 \pm 0.4^{\mathrm{a}}$ & $10.9 \pm 0.3^{\mathrm{a}}$ & $11.4 \pm 0.3^{\mathrm{a}}$ & $11.1 \pm 0.2^{\mathrm{a}}$ \\
\hline Ash & $2.4 \pm 0.2^{\mathrm{a}}$ & $2.4 \pm 0.1^{\mathrm{a}}$ & $2.3 \pm 0.2^{\mathrm{a}}$ & $2.5 \pm 0.1^{\mathrm{a}}$ \\
\hline
\end{tabular}

Whole body GPx and MDA

GPx activity of the control and T-1 groups were similar and significantly $(\mathrm{P}<0.05)$ lower than T-2 and T-3 groups (Fig. 1). There was no significant difference $(\mathrm{P}>0.05)$ in GPx activity between T-2 and T-3 groups (Fig. 1$)$. There was no significant difference $(\mathrm{P}>0.05)$ in MDA content among the treatments (Fig. 2). 


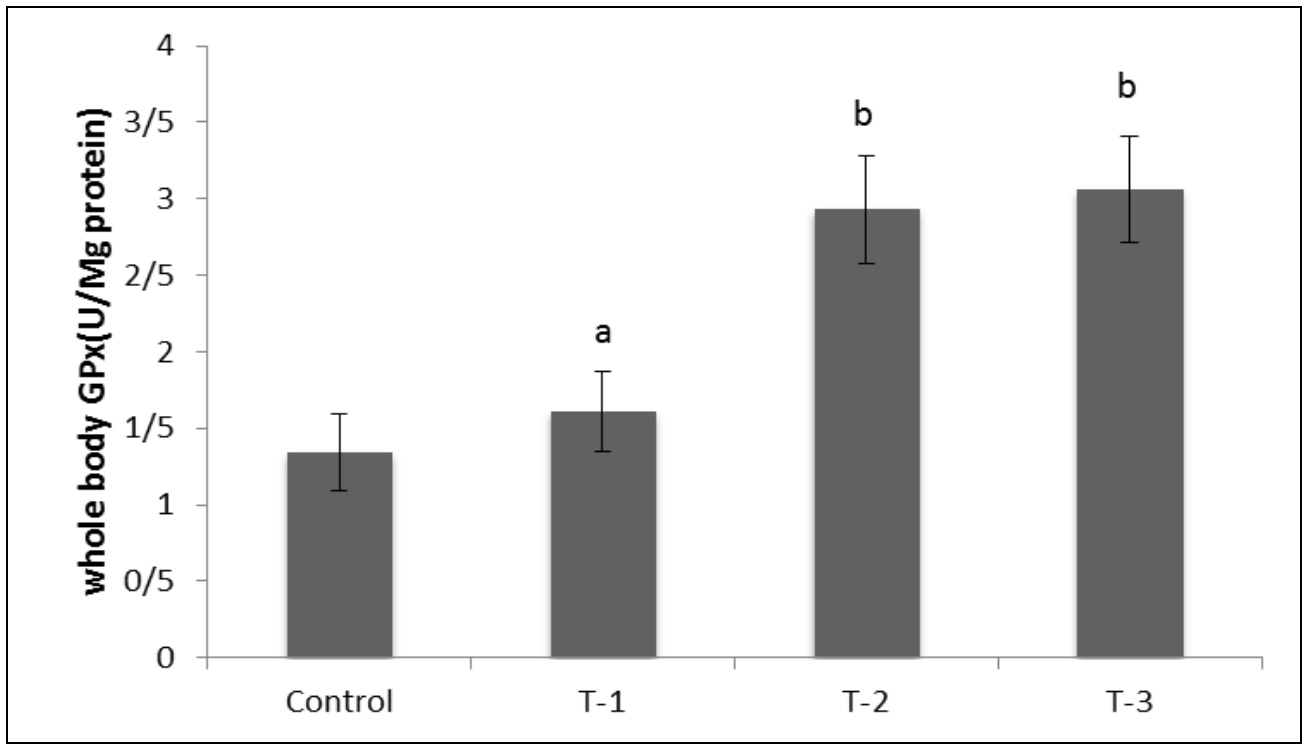

Figure 1: Effect of vitamin E and nano-selenium on body GPx activity of Caspian Kutum.

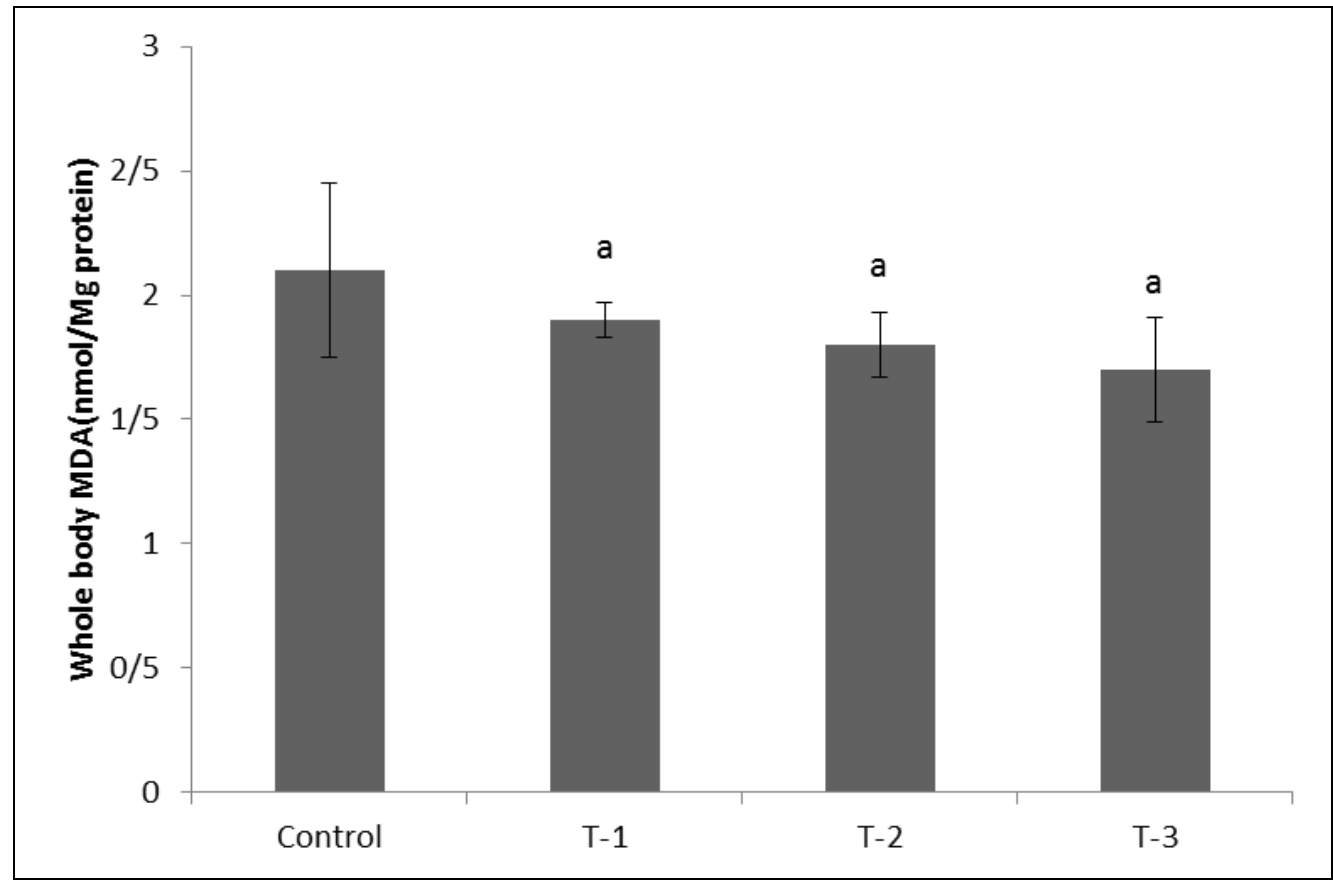

Figure 2: Effect of vitamin E and nano-selenium on whole body MDA content of Caspian Kutum. 


\section{DISCUSSION}

The results of this study showed that the treatments containing vitamin E were significantly different from other treatments with respect to final weight, FCR and WG. Thus it can be stated that vitamin $\mathrm{E}$ was the factor responsible for growth promotion, furthermore, previous studies revealed the effect of vitamin $\mathrm{E}$ on growth promotion (Huang and Huang, 2004; Peng et al., 2009; Amlashi et al., 2011). According to the results obtained in the present study, it can be expressed that nano-selenium had no effect on growth, FCR and GW of Caspian Kutum. This result is not in line with Zhou et al. (2009), which showed that nanoselenium improved growth and FCR in Carassius auratus gibelio. The reasons for this contradiction could be due to lower FCR in Caspian Kutum compared to Carassius auratus gibelio, the presence of selenium in the diets' ingredients, and presence of vitamin E or other antioxidants, such as vitamin $\mathrm{C}$, in the diets covering the role of selenium. However, feeding Senegalese sole (Solea senegalensis) larvae on live food supplemented with organic selenium (Sel-Plex containing selenomethionin) had no beneficial effects on growth and survival (Ribeiro et al., 2012). Also, in another study on Oncorhynchus mykiss, growth was not affected by different levels of Se-yeast and selenite (Rider et al., 2009), which is in line with the present study.

Selenium is a structural component of glutathione peroxidase (Rotruck et al., 1973). In the present study, the whole body GPx activity was measured. The fish receiving the diet containing nano-selenium had higher GPx activity than the other fish, confirming the effect of nano-selenium on GPx activity. Previous studies on the effect of nano-selenium (Zhou et al., 2009) and inorganic or organic selenium (Wang et al., 2007b; Ribeiro et al., 2012; Bell et al., 1985) on fish showed that plasma or liver GPx activity increased because of selenium supplementation. In the present study, GPx activity of the control and T-1 groups were approximately similar. Therefore, it can be stated that vitamin E, without selenium presence, cannot modulate GPx activity. Previous studies on rainbow trout (Bell et al., 1985) and channel catfish (Wise et al., 1993) showed similar results. MDA, produced as a result of lipid peroxidation, is measured as oxidative stress indicator (Esterbauer et al., 1991). In the present study, whole body MDA among the treatments was not significantly different, which could be due to the presence of other antioxidants such as vitamin $C$ in the diets or lack of oxidative conditions during the experiment. Similar to the present study, Zhu et al. (2012) reported an increase in liver GPx activity and no change in MDA content in Micropterus salmoides as a result of feeding on selenium-supplemented diet. Oxidative stress can be induced by a large variety of conditions, including nutritional imbalance, exposure to chemical and physical agents in the environment, strenuous physical activities, injury, and hereditary disorders (Chow, 1991). The Caspian Sea is polluted with heavy metals, oil, industrial wastewater, etc. These pollutions can induced oxidative stress and increased mortality at the time of entering the kutums larva into the sea. According to previous studies (Özkan-Y1lmaz et al., 2013; Mittler, 2002), GPx by decreasing free radicals and finally MDA can increase the resistance of fish against the oxidative stress. On the other hand presence of vitamin $\mathrm{E}$ on diet can improve the final weight, that increase in the final weight of fish and improve the resistance of fish against unsuitable conditions. Overall, the results of the present study showed that nanoselenium could not affect growth performance without the presence of vitamin E. Likewise, vitamin E failed to increase GPx activity, without the presence of selenium. Therefore, it is concluded that both nano-selenium and vitamin E should be added to Caspian Kutum diet to increase growth performance and antioxidant enzyme, particularly GPx, activity. Such conditions can lead to increase in resistance of Caspian Kutum fingerling while entering the sea and afterwards. 


\section{REFERENCES}

1. Abdolhay H. A., Daud S. K., Ghilkolahi S. R., Pourkazemi M., Siraj S. S. and Satar M. A., 2011 - Fingerling production and stock enhancement of Mahisefid (Rutilus frisii kutum) lessons for others in the south of Caspian Sea, Reviews in Fish Biology and Fisheries, 21, 247-257.

2. Afkhami M., Bastami K. D., Shabani N. and Soltani F., 2014 - A survey on ionic and metabolite factors of blood serum in Kutum (Rutilus frisii kutum), Transylvanian Review of Systematical and Ecological Research, 16.2, The Wetlands Diversity, 127-132.

3. Amlashi A. S., Falahatkar B., Sattari M. and Gilani M., 2011 - Effect of dietary vitamin E on growth, muscle composition, hematological and immunological parameters of sub-yearling beluga (Huso huso) L., Fish and shellfish immunology, 30, 807-814.

4. AOAC, 2002 - Official Methods of Analysis of AOAC International (17th edition), Arlington, VA.

5. Bell J., Cowey C., Adron J. and Pirie B., 1987 - Some effects of selenium deficiency on enzyme activities and indices of tissue peroxidation in Atlantic salmon parr (Salmo salar), Aquaculture, 65, 43-54.

6. Bell J., Cowey C., Adron J. and Shanks A. M., 1985 - Some effects of vitamin E and selenium deprivation on tissue enzyme levels and indices of tissue peroxidation in rainbow trout (Salmo gairdneri), British Journal of Nutrition, 53, 149-157.

7. Bell J., Pirie B., Adron J. and Cowey C., 1986 - Some effects of selenium deficiency on glutathione peroxidase (EC 1.11. 1.9) activity and tissue pathology in rainbow trout (Salmo gairdneri), British Journal of Nutrition, 55, 305-311.

8. Chow C. K., 1991 - Vitamin E and oxidative stress, Free Radical Biology and Medicine, 11, 215-232.

9. $\quad$ Ebrahimi G., Ouraji H., Firouzbakhsh F. and Makhdomi C., 2012 - Effect of dietary lipid and protein levels with different protein to energy ratios on growth performance, feed utilization and body composition of Rutilus frisii kutum (Kamenskii, 1901) fingerlings, Aquaculture Research.

10. Esterbauer H., Schaur R. J. and Zollner H., 1991 - Chemistry and biochemistry of 4-hydroxynonenal, malonaldehyde and related aldehydes, Free Radical Biology and Medicine, 11, 81-128.

11. Gatlin D., Poe W. E. and Wilson R. P., 1986 - Effects of singular and combined dietary deficiencies of selenium and vitamin $\mathrm{E}$ on fingerling channel catfish (Ictalurus punctatus), The Journal of Nutrition, 116, 1061-1067.

12. Halver J. E. and Hardy R. W., 2002 - Nutrient flow and retention, Fish nutrition, 3, 755-770.

13. Hamre K., 2011 - Metabolism, interactions, requirements and functions of vitamin $\mathrm{E}$ in fish, Aquaculture Nutrition, 17, 98-115.

14. Heyrati F. P., Mostafavi H., Toloee H. and Dorafshan S., 2007 - Induced spawning of kutum, Rutilus frisii kutum (Kamenskii, 1901) using (D-Ala 6, Pro 9-NEt) GnRHa combined with domperidone, Aquaculture, 265, 288-293.

15. Huang C.-H. and Huang S.-L., 2004 - Effect of dietary vitamin E on growth, tissue lipid peroxidation, and liver glutathione level of juvenile hybrid tilapia, (Oreochromis niloticus) $\times$ (O. aureus), fed oxidized oil, Aquaculture, 237, 381-389.

16. Kei S., 1978 - Serum lipid peroxide in cerebrovascular disorders determined by a new colorimetric method, Clinica Chimica Acta, 90, 37-43.

17. Köhrle J., 2004 - Selenium in biology and medicine - further progress and increasing interest, Journal of Trace Elements in Medicine and Biology, 18, 61-63.

18. Mittler R., 2002 - Oxidative stress, antioxidants and stress tolerance, Trends in plant science, 7, 405-410.

19. NRC, 1993 - Nutrient requirements of fish (NRC), Washington, DC: National Academic Press.

20. Ouraji H., Khalili K. J., Ebrahimi G. and Jafarpour S. A., 2011 - Determination of the optimum transfer time of kutum (Rutilus frisii kutum) larvae from live food to artificial dry feed, Aquaculture International, 19, 683-691. 
21. Özkan-Yılmaz F., Özlüer-Hunt A., Gündüz S. G., Berköz M. and Yalın S., 2013 - Effects of dietary selenium of organic form against lead toxicity on the antioxidant system in Cyprinus carpio, Fish physiology and biochemistry, 1-9.

22. Parker R. and Parker R., 2011 - Aquaculture science, CengageBrain.com.

23. Peng S., Chen L., Qin J., Hou J., Yu N., Long Z., Li E. and Ye J., 2009 - Effects of dietary vitamin $\mathrm{E}$ supplementation on growth performance, lipid peroxidation and tissue fatty acid composition of black sea bream (Acanthopagrus schlegeli) fed oxidized fish oil, Aquaculture Nutrition, 15, 329-337.

24. Peterson G. L., 1977 - A simplification of the protein assay method of Lowry et al. which is more generally applicable, Analytical biochemistry, 83, 346-356.

25. Poston H. A., Combs Jr. G. F. and Leibovitz L., 1976 - Vitamin E and selenium interrelations in the diet of Atlantic salmon (Salmo salar): gross, histological and biochemical deficiency signs, The Journal of Nutrition, 106, 892.

26. Ribeiro A., Ribeiro L., Sæle Ø., Hamre K., Dinis M. and Moren M., 2012 - Selenium supplementation changes glutathione peroxidase activity and thyroid hormone production in Senegalese sole (Solea senegalensis) larvae, Aquaculture Nutrition, 18, 559-567.

27. Rider S. A., Davies S. J., Jha A. N., Fisher A. A., Knight J. and Sweetman J. W., 2009 - Supranutritional dietary intake of selenite and selenium yeast in normal and stressed rainbow trout (Oncorhynchus mykiss): Implications on selenium status and health responses, Aquaculture, 295, 282-291.

28. Rotruck J., Pope A., Ganther H., Swanson A., Hafeman D. G. and Hoekstra W., 1973 Selenium: biochemical role as a component of glutathione peroxidase, Science, 179, 588-590.

29. Wang H., Zhang J. and Yu H., 2007a - Elemental selenium at nano size possesses lower toxicity without compromising the fundamental effect on selenoenzymes: comparison with selenomethionine in mice, Free Radical Biology and Medicine, 42, 1524-1533.

30. Wang Y., Han J., Li W. and Xu Z., 2007b - Effect of different selenium source on growth performances, glutathione peroxidase activities, muscle composition and selenium concentration of allogynogenetic crucian carp (Carassius auratus gibelio), Animal feed science and technology, 134, 243-251.

31. Watanabe T., Kiron V. and Satoh S., 1997 - Trace minerals in fish nutrition, Aquaculture, 151, 185-207.

32. Wise D., Tomasso J., Gatlin D., Bai S. and Blazer V., 1993 - Effects of dietary selenium and vitamin $\mathrm{E}$ on red blood cell peroxidation, glutathione peroxidase activity, and macrophage superoxide anion production in channel catfish, Journal of Aquatic Animal Health, 5, 177-182.

33. Zhou X., Wang Y., Gu Q. and Li W., 2009 - Effects of different dietary selenium sources (selenium nanoparticle and selenomethionine) on growth performance, muscle composition and glutathione peroxidase enzyme activity of crucian carp (Carassius auratus gibelio), Aquaculture, 291, 78-81.

34. Zhu Y., Chen Y., Liu Y., Yang H., Liang G. and Tian L., 2012 - Effect of dietary selenium level on growth performance, body composition and hepatic glutathione peroxidase activities of largemouth bass Micropterus salmoide, Aquaculture Research, 43, 1660-1668. 